\title{
THE ROLE OF ECONOMICS IN FOREST PLANNING AND POLICY EVALUATION IN SLOVENIA
}

\author{
VLOGA EKONOMIJE V GOZDNEM NAČRTOVANJU IN OCENA GOZDNE \\ POLITIKE V SLOVENIJI
}

\author{
Donald HODGES ${ }^{1}$ \\ (1) The University of Tennessee, 274 Ellington Plant Sciences Bldg, Knoxville, TN 37996, USA, dhodges2@utk.edu
}

\begin{abstract}
This paper explores the current status of the forest sectors in Slovenia, identifies potential issues in the management and use of the forests, and discusses a means by which policy makers can identify opportunities to enhance the role played by forests and their related goods and services in Slovenia. Specifically, a framework is proposed to assess the relationships between the economic, social, and ecological aspects of Slovenia's forests; effects of changes in economic conditions on forest demands and uses; economic impacts of ecological, social, and business conditions; effects of current or proposed policies; and opportunities for the sustainable economic development of wood-based and forest-dependent enterprises. Such a framework is critical for managing Slovenia's forests and forestry sector in such a manner to optimize the ecological and economic potential.
\end{abstract}

Key words: economic impacts, smart specialization, wood and paper production, ecosystem services

\section{IZVLEČEK}

Prispevek prikazuje raziskavo stanja gozdarskega sektorja v Sloveniji, pokaže na potencialne težave v upravljanju in rabi gozdov ter odpira razpravo o orodjih, s katerimi bi lahko pripravljavci politik opredelili priložnosti za krepitev vloge gozdov v Sloveniji in z njimi povezanih dobrin in storitev. Podan je predlog okvira za analizo: povezav med ekonomskimi, socialnimi in ekološkimi vidiki gozdov v Sloveniji; vplivov spremenjenih ekonomskih razmer na povpraševanje in rabo gozdnih virov; ekonomskih vplivov ekoloških in socialnih razmer ter poslovnega okolja; učinkov veljavnih in predlaganih politik; in priložnosti za trajnostni ekonomski razvoj podjetništva v lesno-predelovalni panogi in gozdarskem podjetništvu. Tovrstni okvir je ključen za gospodarjenje z gozdovi Slovenije z vidika optimiziranja ekološkega in ekonomskega potenciala gozdarskega sektorja.

Ključne besede: ekonomski učinki, pametna specializacija, lesna in papirna proizvodnja, ekosistemske storitve

\section{INTRODUCTION}

1 UVOD

Forests have long played a critical role in the economic development and environmental and social wellbeing of Slovenia. The nation is one of the most heavily forested countries in Europe, has a long tradition of producing wood products, and currently boasts more species and a greater percentage of its land in the Natura 2000 framework than any other EU member (Ministry of Agriculture and the Environment, 2014). Given this history, it is not surprising that the forests and related products have been identified as key components of the proposed Industrial Policy for Slovenia, specifically wood processing and sustainable tourism (Ministry of Economic Development and Technology, 2013).

The global economic crisis of the 2000s affected most segments of European economies substantially, but the solid-wood based industries were hit the hardest world-wide, due mainly to the collapse of housing markets and the resultant decline in demand (Woodall et al., 2012). The remainder of the paper will explore the current status of the forest sectors in Slovenia, identify potential issues in the management and use of the forests, and discuss a means by which policy makers can identify opportunities to enhance the role that forests and their related goods and services play in Slovenia. Specifically, a framework will be proposed to assess the:

1.relationships between the economic, social, and ecological aspects of Slovenia's forests;

2. effects of changes in economic conditions on forest demands and uses;

3.economic impacts of ecological, social, and business conditions;

4. effects of current or proposed policies; and

5. opportunities for the sustainable economic development of wood-based and forest-dependent enterprises. 
The primary objective of this effort is to illustrate how economics and economic models can assist in the process of smart specialization for the forest-based sectors of Slovenia. Smart specialization is focused on "finding ways to exploit knowledge networks and scale effects in domains where regions had both existing strengths and also the potential for diversification into related sectors, activities, or technologies" (McCann and Ortega-Argilés, 2013, p. 416). The focus is not to develop 'top-down' mandates for specific industries or technologies, but rather encourage entrepreneurship and "diversification around a core set of activities and themes" (McCann and Ortega-Argilés, 2013, p. 417). Sustainable energy, wood, and wood products have been identified in several countries due to resource availability and the 'green' nature of the resource (Rusu 2013). This is particularly true in Slovenia, where the current industrial policy planning highlights forests and wood products predominantly in terms of both renewable energy and key industrial sectors (Ministry of Economic Development and Technology, 2013)

\section{STATUS OF FOREST MANAGEMENT AND WOOD AND PAPER PRODUCTION \\ 2 STATUS GOZDNEGA GOSPODARJENJA TER LESNE IN PAPIRNE PRODUKCIJE}

As stated previously, forests are crucial to economic and cultural life in Slovenia. This section will focus on the economic aspect of forests and wood processing, drawing heavily from the 2013 Statistical Yearbook (Statistical Office of the Republic of Slovenia, 2013), as well as more recent data from the Statistical Office

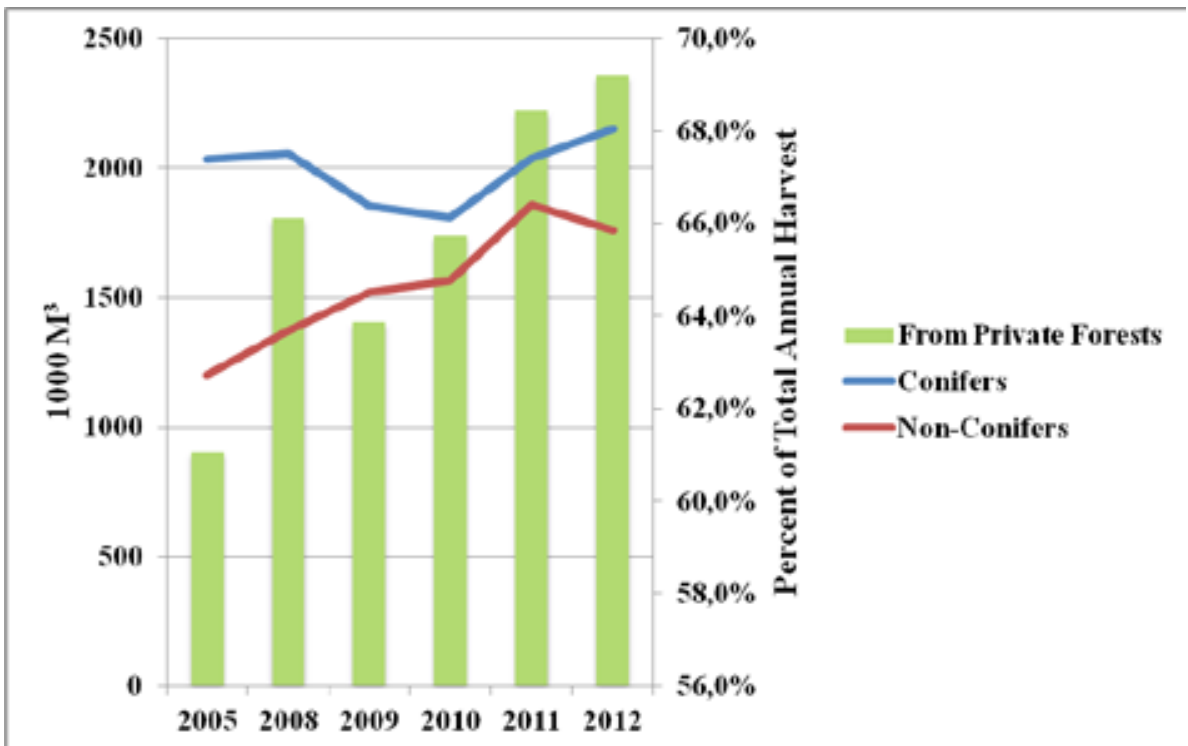

when available. However, other components of the forests' contributions will be considered in discussing the analytical framework. This section will review how the forestry and wood products sectors fared over the last decade and discuss what conclusions can be drawn regarding the current status of the sectors as well as what is needed to project possible future conditions and assess different policy and market scenarios.

Although affected by the economic crisis in the late 2000s, conifer and non-conifer removals from Slovenia's forests have been increasing (Figure 1) (Statistical Office of the Republic of Slovenia, 2013). Conifer removals were affected most by the recession, but still increased by more than 5 percent between 2005 and 2012. Non-conifer removals exhibited much greater growth, even with a downturn between 2011 and 2012, increasing by more than 46 percent between 2005 and 2012. Interestingly, the private forest share of timber removals grew from approximately 60 percent in 2005 to almost 70 percent by 2012. This includes an increase in conifer removals from private forests of almost 20 percent and an increase of more than 67 percent in non-conifer removals from private lands.

The growth in removals has translated primarily into increases in the production of non-conifer saw and veneer logs and pulpwood on a percentage basis (Figure 2). In fact, non-conifer sawlog and veneer log production increased by more than 30 percent and pulpwood production by more than 600 percent between 2005 and 2012. Fuelwood production increased by more than 27 percent. The volume changes during 


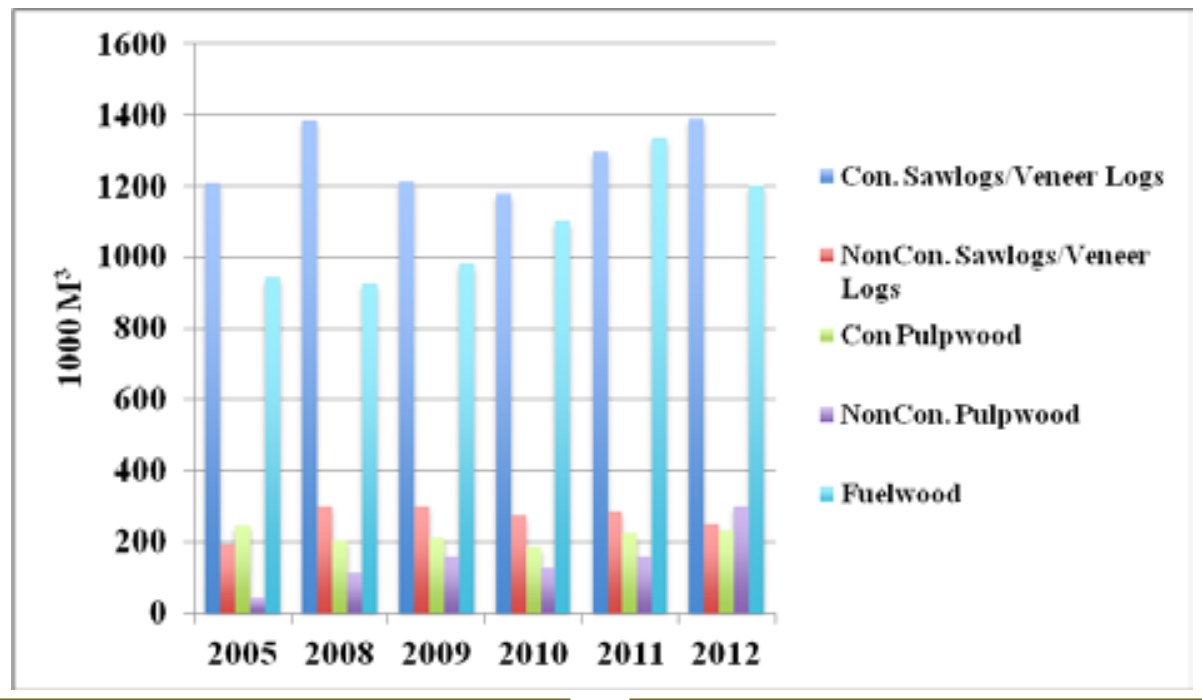

Fig. 2: Removals of conifer and non-conifer sawlogs, veneer logs, pulpwood and fuelwoods in 2005-2012

this period were dominated, however, by increases in pulpwood and fuelwood, which increased by 260,000 and 258,000 $\mathrm{m}^{3}$, respectively, while non-conifer sawlog and veneer production rose by only $60,000 \mathrm{~m}^{3}$.

Similar to removals and production levels, exports increased substantially during the period examined, specifically by more than 250 percent between 2005 and 2013. As Figure 3 illustrates, the increase was driven largely by saw and veneer logs and pulpwood, both of which rose by more than 250 percent. Fuelwood exhibited significant growth as well, more than doubling during the period. At the same time, imports of all wood primary products increased much more slowly
Slika 2: Posek okroglega lesa in hlodov za furnir, lesa za celulozo in drva, podatki so ločeni za iglavce in listavce, $v$ letih 2005-2012

(40 percent), though this can be attributed to an substantial jump in fuelwood imports, much of which was resold outside Slovenia (Lamers et al. 2012). Between 2005 and 2013, the import of saw and veneer logs and pulpwood declined by more than 15 percent (Statistical Office of the Republic of Slovenia 2014a).

An additional indicator highlights the impact of the economic crisis on the wood and paper sectors of Slovenia's economy. Figure 4 depicts the trends in indices for industrial production by sector and the economy as a whole, with 2010 serving as the base year (index = 100) (Statistical Office of the Republic of Slovenia, 2014). As can be seen, both forest-based sectors (wood

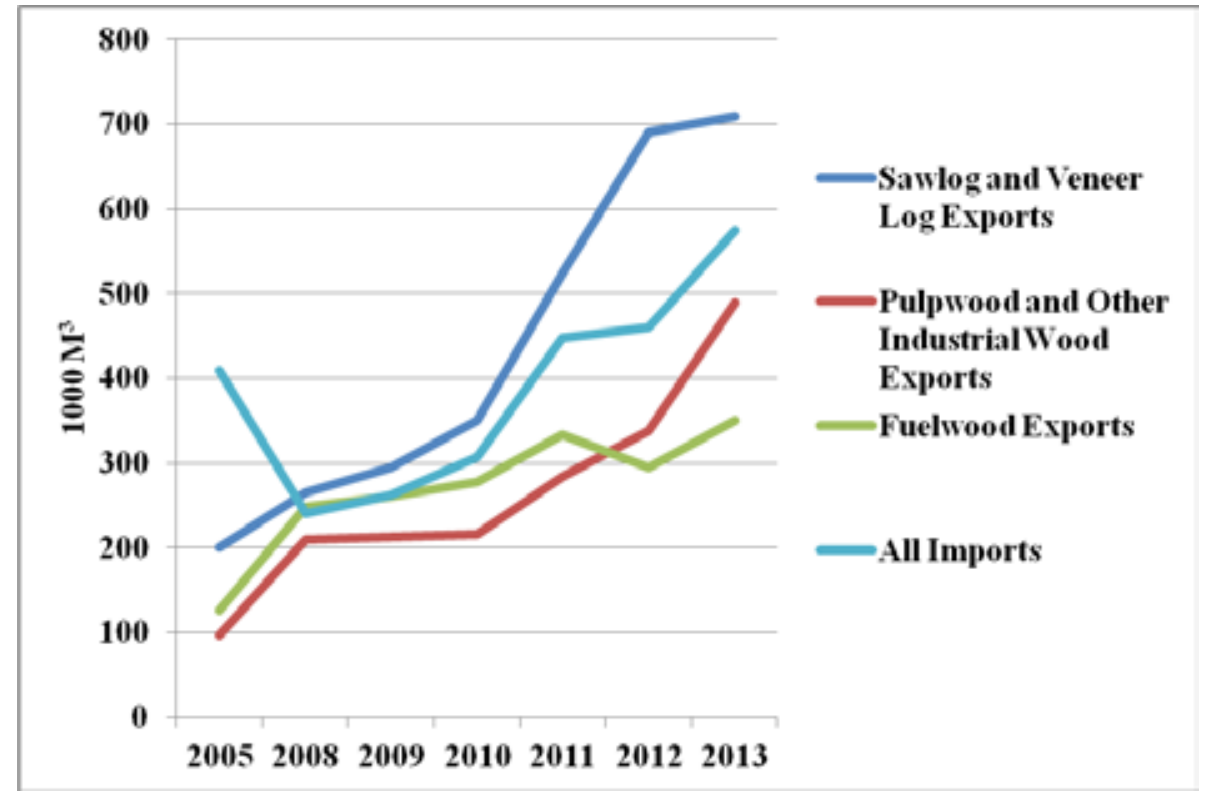

Fig. 3: Export of sawlogs and veneer logs, pulpwood or other industrial wood, and fuelwood and all imports in the 20052013 period
Slika 3: Posek okroglega lesa in hlodov za furnir, lesa za celulozo in drugega industrijskega lesa ter lesa za drva in celoten uvoz v letih 2005-2013 


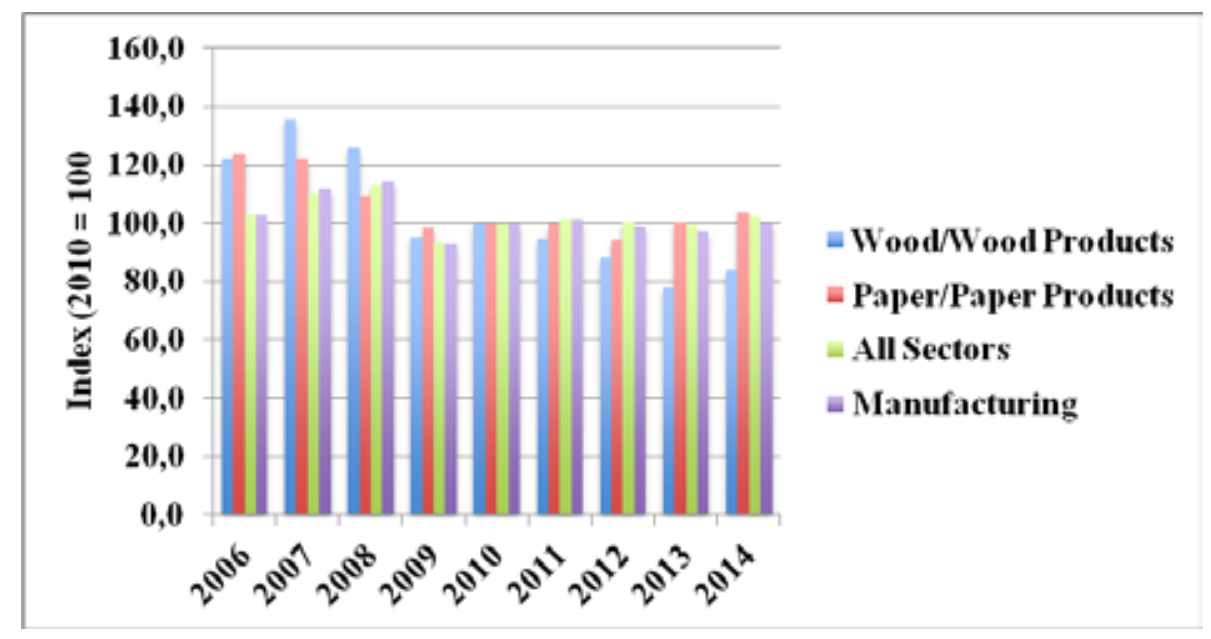

Fig. 4: Indices for industrial production by sector and the economy as a whole, with 2010 serving as the base year and shown for the 2006-2014 period

and wood products, paper and paper products) exhibited substantially greater production growth prior to the major effects of the crisis (pre-2009). After the substantial decline in 2009 for all sectors, the forestbased sectors have been much slower to recover to the pre-2009 levels. Paper and paper products began to exceed production growth of the 'all sectors' and manufacturing by 2013 , but wood and wood products continues to lag by a considerable margin.

Turning to forest management levels, Figure 5 illustrates trends in two primary management activities in Slovenia, regeneration and tending, for all forestland as well as private forests (Statistical Office of the Republic of Slovenia, 2013). Management activities exhibited similar trends as production, with tending declining for private and all forestland between 2005 and 2009, before increasing through 2012 and dropping dramati-
Slika 4: Indeks industrijske proizvodnje po sektorjih za leta 2006-2014. Referenčno leto je 2010.

cally again in 2013. Regeneration levels were relatively more stable during the period examined, but declined substantially in 2013 as well. Significantly, the share of activities conducted on private forests declined significantly between 2005 and 2012. Specifically, the share of regeneration activities conducted on private forests accounted for almost 60 percent of the total area in 2005 , but only 42 percent by 2012 . Similarly, the share of tending that occurred on private forests declined from 53 percent in 2005 to 38 percent in 2012 .

Based on this brief review of the data for the past decade, a few trends are evident. First, the demand for raw materials has recovered from the economic crisis, with removals of both conifer and non-conifer species exceeding pre-2005 levels. Similarly, the production of all raw wood categories exceeds that reported for 2005 , being driven primarily by increases in non-

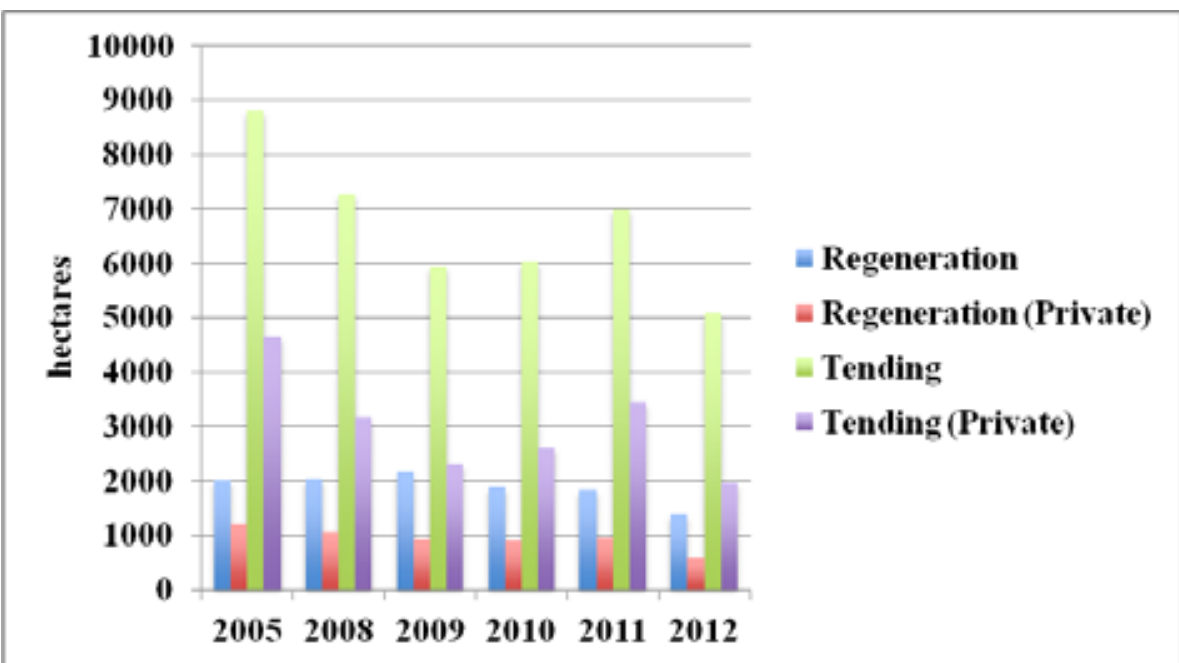

Fig. 5: Trends in two primary management activities (regeneration and tending) in Slovenia with tending declining for private and all forestland between 2005 and 2009, subsequently increasing through 2012 and dropping again in 2013
Slika 5: Trend gospodarjenja (nega in obnova) v zasebnih in vseh gozdovih v Sloveniji. Opazno je zmanjšanje nege med letoma 2005 in 2009, nato postopno povečevanje do leta 2012 in ponoven padec v letu 2013. 


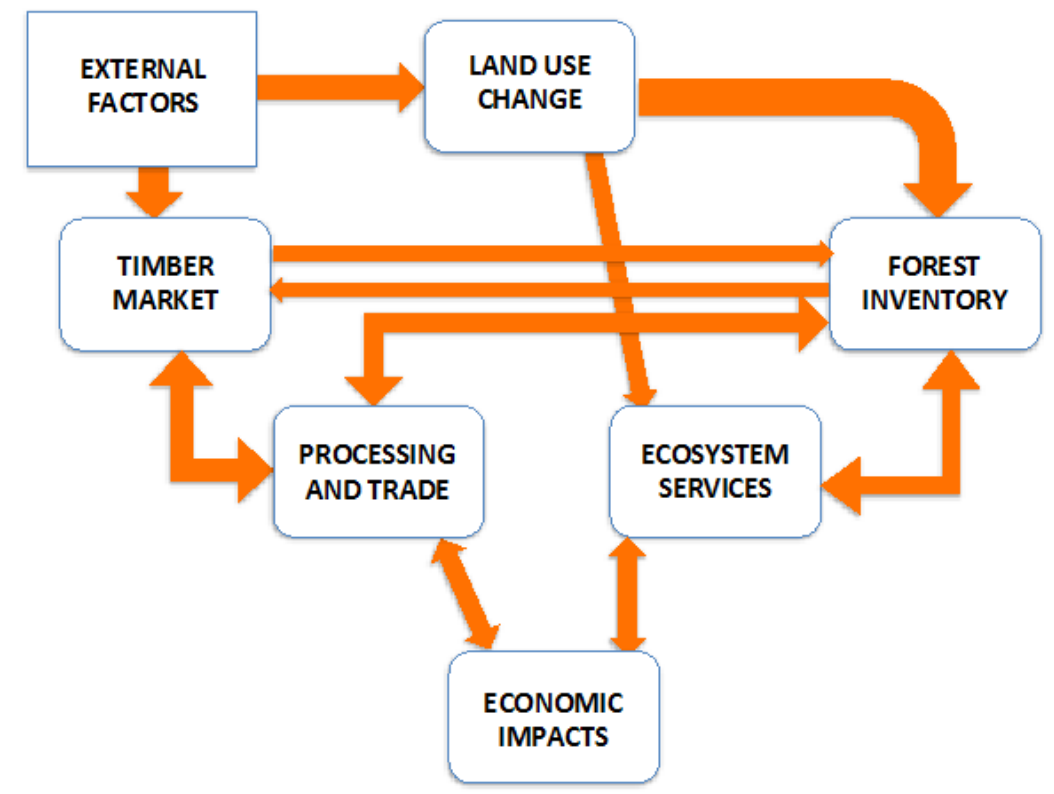

Fig. 6: The proposed framework of six primary modules, with some of the key economic and social variables (e.g. global demand for forest products, inflation, interest rates, energy costs) for Slovenia

conifer production. Much of this increased removals and production is the result of increased use of firewood and pulpwood. Conversely, domestic production continues to struggle to return to pre-2009 levels. Although the paper and paper products sector is nearing production levels achieved before the crisis, solid wood production still lags far behind its historic levels. This problem was also identified by Kropivšek and Jošt (2013), who examined financial indicators for the wood and furniture sectors and noted decreased financial solvency and increased risk for these producers.

Trends in forest management levels present some critical issues as well. As wood removal volumes have increased substantially (see Figure 1), the percentage of this volume originating on private forests has increased from 61 to 69 percent. Thus, private forests are of growing importance for providing material for domestic and international markets. At the same time, however, the level of management activities on this ownership, as reflected by regeneration and tending area (Figure 5), has dropped by more than 50 percent.

Unfortunately, determining how these trends will affect the future conditions of forests, economic activity and social welfare is limited to qualitative judgements based on prior history - unless a more complete analytical framework is developed to capture the relationships between the various economic and physical components of the forest-based economy. Moreover, capturing the effects of the rich diversity of ecosys-
Slika 6: Predlagana shema šestih osnovnih modulov in bistvenih ekonomskih in socialnih spremenljivk (npr. globalne potrebe po gozdnih proizvodih, inflacija, obresti, stroški energije) za Slovenijo

tem services contained within Slovenia's forests on the economy and environment requires that they be included in the analysis as well. Therefore, the remainder of this paper will present a proposed analytical framework to accomplish these objectives, as well as identify priorities for policy making and investment.

\section{ANALYTICAL FRAMEWORK}

\section{ANALITIČNI OKVIR}

Systems to quantify the relationships between the changing conditions of forest stands and economic drivers are not new (see, for example, Adams and Haynes, 1980; Kallio et al., 2004; Latta et al., 2013). Much less common, although growing in use and importance, are systems that also incorporate other aspects of forests such as ecosystem services. The proposed framework for Slovenia includes these other aspects and is comprised of six primary modules, with some of the key economic and social variables (e.g., global demand for forest products, inflation, interest rates, energy costs) exogenous to the framework (Figure 6). These modules will be briefly described below, followed by a discussion of the linkages between the various modules and plan of action.

\subsection{Land use change}

3.1 Sprememba rabe zemljišč

The available land base is a critical component of any projection of the physical and economic aspec- 
ts of forests. A number of factors can affect land use decisions, with population growth, economic activity, commodity (agriculture and timber) prices, and public policy being the most common drivers (Wear, 2011; Verburg et al., 2006). Examining the trends in Slovenia over the past two decades does not reveal much of a change in forest area. Forest area has continued to increase steadily since 1990, after a period of substantial growth between 1960 and 1980, and has remained at approximately 1,18 million hectares since 2008 (Statistical Office of the Republic of Slovenia, 2013). Thus, the model may not be as critical for the traditional drivers of land use change. Climate change, however, is likely to exert considerable influence on European land use change decisions in the future. Hanewinkel et al. (2012), for example, conclude that climate change could affect forest productivity to an extent that much of the value of EU forestland would be lost. This would certainly reduce the incentive for landowners to maintain forest cover. Moreover, the loss in site productivity and species diversity would affect ecosystem service levels as well.

Developing land use change projections, therefore, will require developing econometric models that can account for several variables exogenous to the analytical framework including population growth, commodity prices, income levels. A number of models for this approach have been developed (Wear, 2011; Poudyal et al., 2010; Verburg et al., 2008, 2002) that could be utilized or modified to address the specific conditions in Slovenia. Addressing climate change will require additional work, but could be addressed most easily by utilizing future climate scenarios for the region as part of the forest inventory module.

\subsection{Forest inventory}

\subsection{Gozdna inventura}

The forest inventory module is a critical component for any forest sector modeling effort. Fortunately, the data needed for this module are readily available from the national forest inventory data collected by the Slovenia Forest Service as part of their forest management planning responsibilities and the Forest and Forest Ecosystems Condition Survey (Kušar et al., 2010). The primary outputs from this module include current and projected forest inventory, growth, removals, and mortality by species and location. While the module produces much of the needed information based on the data collected as part of the national inventory and growth and yield estimates, data developed through other components of the framework are needed for these future estimates. Specifically, land use change, projected demand and prices for wood products, and climatic conditions will affect the forest resource base and harvest and growth levels, through linkages with the Timber Market module described below.

\subsection{Timber market}

\subsection{Trg okroglega lesa}

The timber market module, coupled with the forest inventory module, will be used to depict the relationship between forest inventory, prices, and production for Slovenia. In this case, a partial equilibrium model is proposed to determine current and future prices and quantities of forest products produced by Slovenia's forests by region, based on shifts in supply and demand exogenous to the model. This is accomplished by modeling the country's supply and demand as functions of prices, forest inventory, input prices, land management intensity, mill and landowner characteristics, and other demand and supply drivers (Latta et al. 2013; Abt et al., 2000). A recent modeling/mapping effort in Slovenia assessed the demand and supply of the country's wood energy system using the Woodfuels Integrated Supply/Demand Overview Mapping (WISDOM) system (Drigo and Veselič, 2006). Although the study did not evaluate the effects of price changes, the results provide a framework to assess the linkages between potential production levels and consumption.

\subsection{Processing and trade}

\subsection{Predelava in trgovina}

In addition to the timber market and forest inventory linkages, a module is needed to project changes in the wood and paper product sectors and the resulting effects on prices and demand. Estimating the level of international trade and its effect on Slovenia will be an important component of the module as well, given the amount of wood exports. The intent of this component is to better identify the relationships that exist between the processing sectors of the economy, forests, and domestic and international markets. The module also allows for changes in technology to affect forest processing capacity and raw material demand. Drigo and Veselič (2006) developed some of this capability in the wood energy work. The processing and trade component will be closely linked with the two previous modules, given that the outputs of this, the industrial and trade sectors, depend largely on what is physically and economically available. A number of similar models have been developed recently (see, for example, Ince, et al. 2011, Toppinen and Kuuluvainen, 2010). Moreover, the international trade component of the module could easily utilize the Global Forest Prod- 
ucts Model (Buongiorno et al. 2003), as done by Ince et al. (2011) for the U.S. forest products sector.

\subsection{Ecosystem services}

\subsection{Ekosistemske storitve}

The ecosystem services module represents a relatively new addition to forest modeling efforts, but one that is critically important in Slovenia. Increasing demands on ecosystem services and more widely recognized values of natural capital and assets, along with growing ecosystem markets (both regulatory and voluntary), require that all natural resource values be incorporated in management and policy decision making. One of the primary issues to address in this module is which ecosystem services should be included in the analysis. The most logical approach is to focus on those services that are easily measured and for which markets exist, such as carbon sequestration and water quality. Given the diversity of Slovenia's forested ecosystems, biodiversity is another candidate to be included.

Estimating the level of ecosystem services will be relatively straightforward for some services, carbon being the most obvious. To a large degree, calculating ecosystem service quantities will rely heavily on the forest inventory data. In a study designed to estimate carbon sequestration potential for broadleaf forests in the southern U.S., for example, Hodges and Hale (2014) describe the field inventory necessary to determine timber volumes, carbon sequestration potential, and total biomass - all required for carbon sequestration programs that compensate landowners. This includes tree species, product classes and volumes, carbon, total biomass (above and below ground), and growth. Figure 7 illustrates the resulting data that can be incorporated into a spatial equilibrium model. Similar approaches can be applied to select ecosystem services in Slovenia, as well as variations in these levels due to changes in forest conditions projected in the related modules of the proposed framework.

\subsection{Economic impacts}

3.6 Ekonomski učinki

The five modules described above (Land Use Change, Forest Inventory, Timber Market, Processing and Trade, and Ecosystem Services) are focused exclusively on the forests and forestry sectors, linking to external factors only to project changes within these modules. Conversely, the final component of the proposed Analytical Framework - Economic Impacts - is designed to translate the projected changes and trends in the forests and forestry sectors on the larger economic and social aspects of Slovenia. At the same time, the changes in the economy that are estimated in this module can inform the other components regarding future conditions.

The Economic Impacts module, therefore, is the component that provides much of the information to

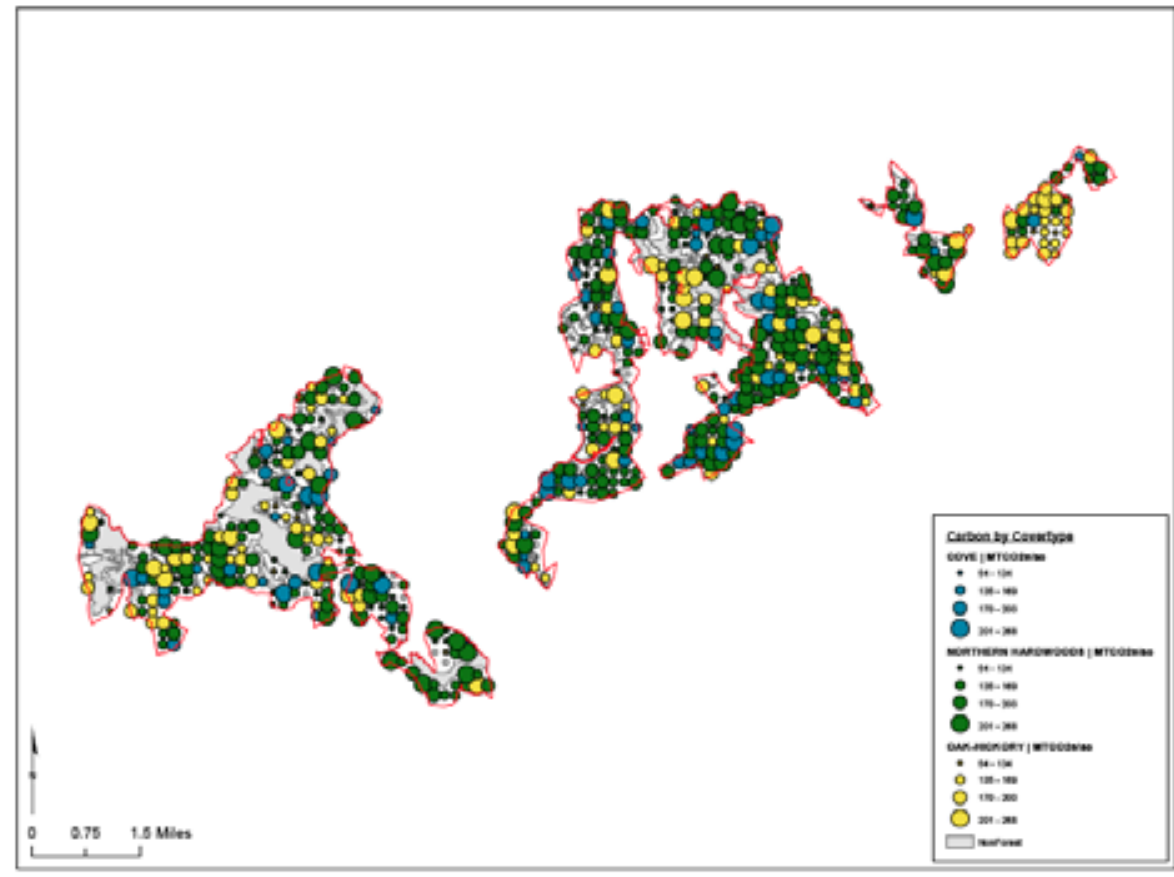

Fig. 7: An example of the level of ecosystem services estimation for southern U.S. (Hodges and Hale 2014) that can be incorporated into a spatial equilibrium model
Slika 7: Primer ocene stopnje uporabe ekosistemskih storitev v južnem delu Združenih držav Amerike (Hodges in Hale 2014), ki jo lahko uporabimo za vključevanje v prostorske modele 
meet three of the objectives listed in the Introduction. Specifically, the module, based on the results of the Framework, will provide estimates of the economic impacts of ecological, social, and business conditions; effects of current or proposed policies; and opportunities for the sustainable economic development of wood-based and forest-dependent enterprises. Information that can be generated from this component includes changes in employment, income, tax revenue, production, value-added, and other indicators of economic change.

A number of alternative approaches are available to conduct this analysis, and similar models have been developed for selected portions of the forestry sector or other components of the economy in Slovenia. Krajnc and Domac (2005), for example, developed a model to assess the socio-economic impacts of biomass use in Slovenia. Stoforus et al. (2000) developed a "partial equilibrium, dynamic, multi-market, synthetic and policy oriented simulation model" to evaluate economic effects of alternative policy scenarios on the Slovenian economy, with a specific emphasis on agriculture. The approach that is proposed here is to utilize some form of national accounting model such as input-output analysis or a general equilibrium model that would estimate the economic consequences of changes in the forest and forestry sectors throughout the economy.

\section{DISCUSSION}

\section{RAZPRAVA}

The brief description of the components of an Analytical Framework for assessing the linkages between the national (and global) economy, Slovenian forests, and the forest products sectors is intended to provide some insight into how such an approach would benefit decision makers in both the forestry and national policy arenas. Overall, economics and economic models can be extremely useful to applying smart specialization concepts for forestry, wood science, and manufacturing in at least four ways. First, economics can identify critical problems and key opportunities in supply chains from a wood processing perspective. Economics can also be useful in providing insights into how new policy or changes in existing policies can affect resource demand, production levels, and economic conditions; as well as assessing the long-term impacts of forest management decisions on forest sustainability and economic vitality. Finally, economic assessments can provide an extremely effective means of identifying and evaluating emerging opportunities such as those offered by bioenergy and ecosystem services. These contributions of economics can be critical in demon- strating the role that forests, wood industry, and woodbased energy can play in smart specialization efforts in Slovenia, suggesting that the proposed framework is critical if policy makers are to understand the implications of their decisions regarding Slovenia's natural resources and economy.

As stated previously, Slovenia has a rich diversity of forests that are critical to a strong forest products industry and thriving tourism economy. Constructing all of the necessary components of the framework will require a number of years, although some modules are already developed for use (such as the Global Forest Products Model), or 'first generation' versions of other modules can be developed for preliminary evaluation relatively quickly. Bončina et al. (2013) provide an excellent review of the efforts to develop Forest Decision Support Systems (DSS) in Slovenia. Many of these efforts could be easily adapted as well. A reasonable plan of action would be to focus attention on the basic components (Land Use Change, Forest Inventory, Timber Market) initially. Once these are functioning, the remaining components can be incorporated into the framework. The Processing and Trade and Economic Impacts modules will most likely be modified versions of existing models, which should reduce the time required to develop a functioning version for Slovenia. The Ecosystem Services module may require more time to develop, but efforts are underway in Slovenia and the region to develop preliminary estimates of these quantities, so some values might be available. Regardless of the timing of module development, it is critical that framework development and planning identify all of the critical linkages and data needs so that all required information is incorporated into the appropriate modules.

From a smart specialization perspective, developing a framework that explores the linkages between the ecological, economic, and social components of the forest sector will ensure that 1 ) research can be focused on elements that will have the greatest impact on future productivity, 2) the emphasized sectors will positively affect economic development, and 3) ecological and social sustainability are achieved. Such information is needed if Slovenia's forests are managed in such a manner to optimize the ecological and economic potential.

\section{SUMMARY}

\section{POVZETEK}

$\mathrm{V}$ članku analiziramo trenutno stanje gozdnih sektorjev v Sloveniji, opredeljujemo možne težave pri upravljanju in rabi gozdov in razpravljamo o načinu, s 
katerim lahko odločevalci prepoznajo priložnosti, da se okrepi vloga, ki jo imajo gozdovi in z njimi povezani proizvodi in storitve v Sloveniji. Opisanih je več trendov glede trenutnega stanja gozdov v državi in gozdarske industrije. Prvič, povpraševanje po surovinah si je opomoglo od gospodarske krize, in sicer tako pri odvozu iglavcev kot listavcev, kar presega raven pred letom 2005. To povečanje je predvsem posledica povečane selitve proizvodnje $v$ tujino in širitev izvoznih trgov, pri čemer se je izvoz lesa samo $\mathrm{v}$ analiziranem obdobju povečal za 200 odstotkov. Hkrati pa domača proizvodnja še vedno ni dosegla ravni pred letom 2009. Rast smo zabeležili tudi v sektorju papirne industrije, saj se je raven proizvodnje približala tisti pred krizo, medtem ko proizvodnja lesa še vedno izraziteje zaostaja. Povečevanje proizvodnje lesa je treba pripisati predvsem povečanju v zasebnih gozdovih, tako da so slednji pomembnejši vir ne zgolj za domače, marveč tudi tuje trge, vendar pa ni dorečeno, kako bodo omenjeni trendi vplivali na gospodarjenje z gozdovi in $\mathrm{z}$ njimi povezanimi gospodarskimi panogami.

Podan je predlog okvira za analizo: povezav med ekonomskimi, socialnimi in ekološkimi vidiki gozdov v Sloveniji; vplivov spremenjenih ekonomskih razmer na povpraševanje in rabo gozdnih virov; ekonomskih vplivov ekoloških in socialnih razmer ter poslovnega okolja; učinkov veljavnih in predlaganih politik; in priložnosti za trajnostni ekonomski razvoj podjetništva $\mathrm{v}$ lesno-predelovalni panogi in gozdarskem podjetništvu. Tovrstni okvir je ključen za gospodarjenje z gozdovi Slovenije z vidika optimiziranja ekološkega in ekonomskega potenciala gozdarskega sektorja.

\section{ACKNOWLEDGEMENTS}

\section{ZAHVALA}

I wish to thank Anže Japelj and an anonymous reviewer for their many helpful suggestions.

\section{REFERENCES}

\section{VIRI}

Abt R.C., Cubbage F.W., Pacheco G. 2000. Southern forest resource assessment using the subregional timber supply (SRTS) model. Forest Products Journal, 50, 4: 25-33.

Adams D. M., Haynes R.W. 1980. The 1980 softwood timber assessment market model: structure, projections, and policy simulations. Forest Science Monograph 22. 64 p.
Bončina, A., Ficko, A., Krč, J., Matijšac, D., Pisek, R. Poljanec, A., Simončič, T. 2013. Computer-based tools for supporting forest planning and management in Slovenia. In: Borges, J.G., Nordström, E.M., García-Gonzalo, J., Hujala, T., Trasobares, A. (eds). Computer-based tools for supporting forest management. The experience and the expertise world-wide. Report of Cost Action FP 0804 Forest Management Decision Support Systems. Swedish University of Agricultural Sciences Department of Forest Resource Management, Umeå. pp. 320-340.

Buongiorno J., Zhu S., Zhang D., Turner J., Tomberlin D. 2003. The global forest products model. Maryland Heights, MO: Academic Press (Elsevier). $301 \mathrm{p}$.

Drigo, R. and Veselič., Ž. 2006. Woodfuel Integrated Supply / Demand Overview Mapping (WISDOM) - Slovenia - Spatial woodfuel production and consumption analysis. FAO Forestry Department Wood Energy Working Paper. FAO.

Hanewinkel M., Cullmann D.A., Schelhaas M-J, Nabuurs G-J., Zimmermann N.E. 2012. Climate change may cause severe loss in the economic value of European forest land. Nature Climate Change, 3: 203-207.

Hodges D.G., Hale D.S. 2014. Decision support system to assess the role of ecosystem services in adapting to shifting framework conditions. In: Adaptation in Forest Management Under Changing Framework Conditions, Proceedings, International Symposium of International Union of Forestry Research Organizations, Combined Conference of Research Groups 3.08 (Small-Scale Forestry) and 4.05 (Managerial Economics and Accounting), E. Schiberna and M. Stark, editors. pp. 87-92.

Ince P.J., Kramp A.D., Skog K.E., Spelter, H.N., Wear D.N. 2011. U.S. Forest Products Module: A Technical Document Supporting the Forest Service 2010 RPA Assessment. Research Paper FPL-RP-662. Madison, WI: U.S. Department of Agriculture, Forest Service, Forest Products Laboratory. $61 \mathrm{p}$.

Kallio I.M.A., Moiseyev A., Solberg B. 2004. The EFI Forest Sector Global Trade Model (EFI-GTM) - The Model Structure. European Forest Institute Internal Report No. 15. 24 p.

Krajnc N., Domac J. 2005. Computer model for the assessment of socio-economic and environmental aspects of biomass use - a comparison of the results obtained in two regions in Slovenia and Croatia. Zbornik gozdarstva in lesarstva, 77, 85-112. ISSN 0351-3114

Kropivšek J., Jost M. 2013. Financial analysis of Slovenian wood industry. in "WoodEMA: Innovation as the source of values in the forestry, wood processing and furniture manufacturing. Częstochowa, Poland: International Association for Economics and Management in Wood Processing and Furniture Manufacturing.

Kušar G., Kovač M., Simončič P. 2010. Methodological bases of the forest and forest ecosystem condition survey. In: Control Sampling Method in Slovenia - History, Characteristics and Use, Marko Kovač et al. editors. Slovenia Forest Institute, Ljubljana. pp. 11-22.

Latta G.S., Sjolie H.K., Solbeg B. 2013. A review of recent developments and applications of partial equilibrium models of the forest sector. Journal of Forest Economics, 19, 4: 350-360.

McCann, P., Ortega-Argilés, R. 2013. Transforming European regional policy: a results-driven agenda and smart specialization. Oxford Review of Economic Policy 29, 2: 405-431.

Ministry of Agriculture and the Environment. 2014. NATURA 2000: The Treasures of Slovenian Nature. 2014. Available from: http:// www.natura2000.gov.si/index.php? id=18\&L=1. 
Ministry of Economic Development and Technology. 2013. Slovenian Industrial Policy. Publication Number 31000-1/2013/5. Ljubljana. $77 \mathrm{p}$.

Poudyal N.C., Cho S., Strickland J.D., Hodges D.G. 2010. An analysis of forestland change on the northern Cumberland Plateau: bridging the broad units and fine units datasets in a landuse model. In: Global Change and Forestry: Economic and Policy Impacts and Responses, J. Gan, S. Grado, and I.A. Munn, editors. Nova Science Publishers, Inc., Hauppauge NY. pp. 63-76.

Rusu, M. 2013. Smart specialization a possible solution to the new global challenges. Procedia Economics and Finance 6: 128-136.

Statistical Office of the Republic of Slovenia. 2013. Statistical Yearbook 2013 of the Republic of Slovenia, $52^{\text {nd }}$ issue. Ljublajana. ISSN 1318-5403.

Statistical Office of the Republic of Slovenia. 2014a. Roundwood export and import, Slovenia 2013 - final data. SI-STAT Data Portal. http://www.stat.si/eng/novica_prikazi. aspx?id=6525. Last Accessed: 1 December.

Statistical Office of the Republic of Slovenia. 2014b. Indices of industrial production by main industrial groups according to statistical classification of economic activities NACE Rev. 2. SI-STAT Data Portal. http://pxweb.stat.si/pxweb/Database/Economy/17_mining_ manufac/17011_industrial_prod/17011_industrial_prod.asp. Last Accessed: 1 December 2014.

Stoforos C., Kavcic S., Erjavej E., Mergos G. 2000. Agricultural policy analysis model for Slovenian agriculture. In : Giannias D.A. (ed.), Mergos G. (ed.). Selected readings on economies in transition. Chania : CIHEAM, 2000. p. 91-102 (Cahiers Options Méditerranéennes; n. 44).
Toppinen A., Kuuluvainen J., 2010. Forest sector modelling in Europe-the state of the art and future research directions. Forest Policy and Economics 12, 1: 2-8.

Verburg P., Schulp C.J.E., Witte N., Veldkamp A. 2006. Downscaling of land use change scenarios to assess the dynamics of European landscapes. Agriculture, Ecosystems and Environment, 114: 39-56.

Verburg P., Eickhout B., van Meijl H., 2008. A multi-scale, multi-model approach for analyzing the future dynamics of European land use. The Annals of Regional Science, 42, 57-77.

Verburg, P.H., Soepboer, W., Veldkamp, A., Limpiada, R., Espaldon, V., Mastura, S.A. 2002. Modeling the spatial dynamics of regional land use: the CLUE-S model.Environmental Management, 30: 391-405.

Wear D.N. 2011. Forecasts of county-level land uses under three future scenarios: a technical document supporting the Forest Service 2010 RPA Assessment. Gen. Tech. Rep. SRS-141. Asheville, NC: U.S. Department of Agriculture Forest Service, Southern Research Station. $41 \mathrm{p}$.

Woodall C.W., Ince P.J., Skog K.E., Aguilar F.X., Keegan C.E., Sorenson C., Hodges D.G., and Smith W.B. 2012. An overview of the forest products sector downturn in the United States. Forest Products Journal 61, 8: 595-603. 